11. Lewis, P., \& Willer, D. (2017). Does Social Value Orientation Theory Apply to Social Relations?. Sociological Science, 4, 249-262. doi:10.15195/v4.a11

12. LIU, C., \& HAO, F. (2012). Social Value Orientation and Cooperation in Asymmetric Social Dilemmas. Acta Psychologica Sinica, 43(4), 432-441. doi:10.3724/sp.j.1041.2011.00432

13. McDermott, R. (2004). Prospect Theory in Political Science: Gains and Losses From the First Decade. Political Psychology, 25(2), 289-312. doi:10.1111/j.1467-9221.2004.00372.x

14. Popovych, I. (2015). Social"ni ochikuvannya v lyuds"kyx vzayemynax [Social expectations in human relationships]. Seriya : Psyxolohiya, 2, 144153. [in Ukrainian].

15. Ray, K., \& Castillo, L. (2017). Moral Bioenhancement, Social Biases, and the Regulation of Empathy. Topoi, 38(1), 125-133. doi:10.1007/s11245017-9468-6

16. Rushworth, M., \& Walton, M. (2009). Neuroeconomics: Decision Making and the Brain. Neuron, 63(2), 150-153. doi:10.1016/j.neuron.2009.07.005

17. Schmid, D. (2014). "Quo vadis, Homo harzburgensis?". Zeitschrift für Unternehmensgeschichte, 59(1), 73-98. doi:10.1515/zug-2014-0105
18. Semyonov, Igor. (2018). Vklad A. N. Leont'eva v razvitie psihologii myshlenija, inzhenernoj psihologii i jergonomiki [Leontiev's contribution to the development of thinking psychology, engineering psychology and ergonomics]. Vestnik Moskovskogo universiteta, 14. [in Russian]

19. Singer, T., \& Lamm, C. (2009). The Social Neuroscience of Empathy. Annals of the New York Academy of Sciences, 1156(1), 81-96. doi:10.1111/j.1749-6632.2009.04418.x

20. Smith, A. (2018). The Theory of Moral Sentiments. La Vergne: Neeland Media LLC.

21. Tammi, T. (2011). Contractual preferences and moral biases: social identity and procedural fairness in the exclusion game experiment. Constitutional Political Economy, 22(4), 373-397. doi:10.1007/s10602-011-9111-2

22. Tasch, W., \& Houser, D. (2018). Social Preferences and Social Curiosity. SSRN Electronic Journal. doi:10.2139/ssrn.3211794

23. Thoron, S. (2016). Morality Beyond Social Preferences: Smithian Sympathy, Social Neuroscience and the Nature of Social Consciousness. OEconomia, (6-2), 235-264. doi:10.4000/oeconomia.2373

Надійшла до редколегії 15.09.20

Рекомендована до друку 22.10.20

Alla Kovalenko, Dr. Sc (Psychology), Prof.

Albina Holovina, PhD student (Psychology)

Taras Shevchenko National University of Kyiv, Kyiv, Ukraine

\title{
SHIFTING SOCIAL PREFERENCES TOWARDS MORAL PREJUDICES IN A PROCESS OF RESOURCE ALLOCATION DECISION MAKING
}

This paper presents an analysis of the main theories and results of experimental research in the context of the shifting social preferences towards moral prejudices in a process of resource allocation decision making. Researchers of game theory have found that three motives are included in the decision-making process about resource allocation: social preferences, moral prejudices, and self-interest. Personal interests and moral prejudices are strong predictors in the model of predicting people's social orientations. Moral prejudices, being the distortions created by self-interest, can strongly influence people's social preferences, and even change them to the opposite. As a result, an asymmetric relationship is established between personal interest and moral prejudices in the decision-making process about resource allocation. When moral prejudices become an obstacle to achieving a goal, a person unconsciously distorts the information so that it justifies its actions. These distortions can be manifested in the avoidance of information that interferes with personal interests, the selective selection of information, and even recourse to opposing moral principles. In the long run, all this is expressed in the change of a person's social orientation from altruistic to selfish. These changes in people's social preferences are confirmed by the results of numerous experiments not only in social psychology, but also in social neuropsychology and neuroeconomics. The way to overcome these distortions is to have a clear understanding of the limits of personal interests and an understanding of one's own motives in decisions about resource allocation.

Keywords: altruism, game theory, homo economicus, motivation, moral prejudice, personal interest, social preference.

Bulletin of Taras Shevchenko National University of Kyiv. Series "Psychology". № 1(11), pp. 36-42 (2020) УДК 159.923

DOI: https://doi.org/10.17721/BSP.2020.1(11).7
ISSN 1728-3817

(c) Taras Shevchenko National University of Kyiv,

Publishing and Polygraphic Center "Kyiv University", 2020

Ольга Купрєєва, канд. психол. наук, доц.
Київського національного університету імені Тараса Шевченка, Київ, Україна

\section{ПСИХОЛОГІЧНІ ФАКТОРИ ЖИТТЕСТІЙКОСТІ СТУДЕНТІВ З ІНВАЛІДНІСТЮ}

У статті викладено результати емпіричного дослідження психологічних факторів життєстійкості студентів з інвалідністю. Метою є дослідження психологічних особливостей, факторів та предикторів які детермінують життєстійкість студентів з інвалідністю. Методи. Факторним аналізом визначено параметри життєстійкості студентів з інвалідністю з різним рівнем вираженості їі компонентів. За результатами регресійного аналізу спрогнозовано показники життєстійкості студентів з інвалідністю з низьким та середньо-високим рівнями інтегральної життєстійкості. Висновки. Отримані дані дозволяють визначити ресурси життєстійкості студентів з інвалідністю та будуть використані під час побудови комплексної програми психологічного сприяння особистісній самореалізації студентів в умовах інтегрованого навчання.

Ключові слова: життєстійкість, студенти з інвалідністю, ресурси особистості, інтегроване навчання.

Вступ. Інклюзія у вищій освіті - це шлях реалізації гуманістичних ідей альтруїзму, толерантності, який забезпечує рівноправний доступ до здобуття освіти, реалізації себе в професії, визнання унікальності, неповторності людини, включення кожного "різного" у повноцінне життя суспільства, культуру в цілому, осмислення власного життя та життя інших.

Разом з тим, навчання в інтегрованих групах - це виклик особливої складності для студентів з інвалідністю, які наважуються реалізувати власні права та рівні можливості в умовах інклюзії у вищій школі, оскільки, вони приймають виклик "на рівних" в умовах дефріциту власних ресурсів. Цей виклик не стільки ставить межі можливостям саморозвитку, самореалізації студентів 3 інвалідністю, скільки вимагає від них використання зна- чно більших зусиль та активізації особистісних ресурсів, ніж у ситуаціях звичайного, необтяженого хронічною хворобою, розвитку особистості.

Фокус уваги дослідників гуманістичного та позитивного підходу до функціонування особистості в несприятливих умовах розвитку (до яких відносять ситуацію інвалідності), спрямований на виявлення тих особистісних характеристик які дозволяють суб'єкту позитивно існувати - ефективно долати труднощі, досягати самореалізації та психологічного благополуччя (Maddi, 2013; Seligman, Scikszentmihalyi, 2000;).

Особливого значення під час дослідження розвитку осіб з інвалідністю надають життєстійкості - базовій характеристиці особистості, системі її установок та переконань, яка опосередковує вплив на свідомість та 
поведінку людини несприятливих ситуацій життєдіяльності (від соматичних захворювань до соціальних проблем) (Maddi, 2013); як ресурсу особистості, який сприяє ії̈ успішній адаптації, допомагає долати складні ситуації у процесі навчальної та професійної діяльності, актуалізує різноманітні особистісні характеристики в несприятливих умовах розвитку (Maddi, Khoshaba, Harvey \& Fazel 2010), виконує важливу буферну функцію (Peterson, \& Seligman, 2004), та сприяє укріпленню фрізичного та психічного здоров'я людини, самоствердженню та самореалізації особистості.

Згідно з поглядами С. Мадді (Maddi, 2004) концепт "життєстійкість" включає психологічний (підвищений інтерес до оточуючого середовища, особистісні смисли, самоставлення та ставлення до оточуючих) та діяльнісний (подолання різноманітних викликів, досягнення цілей, турбота про здоров'я) компоненти.

Ми вважаємо важливим вивчення даного феномену у студентів з інвалідністю, оскільки сама особистість, ії позиція, ставлення та активність впливають на процес та результат саморозвитку. Дослідження параметрів особистості які розширюють структуру індивідуальної життєстійкості, та їх цілеспрямований розвиток, буде сприяти стійкості та ефективній самореалізації студентів $з$ інвалідністю.

Мета дослідження - виявити психологічні особливості, фрактори та предиктори які детермінують життєстійкість студентів з інвалідністю.

Методи дослідження. Теоретичний огляд літератури з досліджуваної проблеми, емпіричні методи дослідження та методи математичної обробки емпіричних даних.

Огляд літератури. У сучасних психологічних дослідженнях проблематика подолання особистістю ускладнених умов розвитку, які можуть бути задані генетичними особливостями, соматичними захворюваннями, набутими фізичними дефектами та негативно впливати на її життєдіяльність, досліджується шляхом цілісного осмислення особистісних характеристик, які відповідають за подолання життєвих труднощів (Купрєєва, 2020; Леонтьєв, Александрова, Лебєдєва, 2017; Осьмук, 2018; Селіванова, Скляров, 2020; Шамич, 2019). Однією з таких характеристик $€$ життєстійкість особистості - психологічна живучість, ефективність людини та показник її психічного здоров'я.

B дослідженнях американських психологів D. Khoshaba and S. Maddi (1999), які вперше ввели поняття "hardiness", цей феномен має три компоненти: включеність, контроль та прийняття ризику (виклику).

Перший компонент "включеність" відображає відчуття прихильності життєвим задачам, установку людини по відношенню до себе, оточуючого світу та характеру взаємодії з ним, яка надає сили, мотивує ії до самореалізації, позитивному мисленню та ефективної поведінки. Включеність людини у вирішення власних життєвих завдань допомагає відчувати себе цінним та значимим, здатним долати щоденні труднощі та зміни, а стресові ситуації трансформувати в ресурс саморозвитку.

Другий компонент контроль над обставинами, мінливими життєвими подіями відображає здатність людини, або пошук способів, вплинути на результати стресових ситуацій, не впадати у стан пасивності, безпорадності.

Третій компонент - виклик як настанова людини сприймати стресові ситуації та проблеми як виклик, випробування себе, а не як загрозу. Це зумовлює здатність особистості бути відкритою оточуючому світу, людям, розвиватися шляхом отримання знань, через досвід та активне його використання.
Сформованість всіх трьох компонентів психологічної життєстійкості $€$ важливим для підтримання ефективної діяльності, активності у стресових ситуаціях, фізичного та психологічного здоров'я (Maddi, 2006).

Отже, життєстійкість - це внутрішній ресурс, який підвладний самій людині та може бути використаний відповідно до ситуацій. Він дозволяє перетворювати зміни в можливості, саме тому, людина може змінити і переосмислити те, що сприяє підтриманню фрізичного, психологічного, соціального здоров'я, настанова, яка надає життю цінності та смислу в будь-яких обставинах (Maddi, 2013).

У психологічній літературі розглядають різні параметри особистості які пов'язані з психологічною життєстійкістю особистості: особистісна автономія (Serdiuk, Danyliuk \& Chykhantsova, 2019); осмисленість життя (Ryff, \& Singer, 1998); смисложиттєві орієнтації, позитивне самоставленням особистості (Сердюк, Купрєєва, 2015); самоефективність (Bandura, 1997; Schwarzer \& Jerusalem, 1995); локус контролю (Jomehri, Najafi, Jafari \& Sohrabi, 2009); оптимізм та позитивний настрій (Mahdian, Ghaffari, 2016); надія (Najmeh, 2020) тощо.

Ми розглядаємо життєстійкість як цілісну характеристику особистості, необхідний ресурс який сприяє покращенню та підтриманню психічного і фрізичного здоров'я, успішній адаптації у складних умовах розвитку та життєдіяльності, ситуаціях вибору, пов'язаних 3 особистісним, професійним самовизначенням та самореалізацією.

Крім визначених компонентів, на нашу думку, життєстійкість включає наступні важливі фрактори та компоненти: базові цінності та переконання, як імпліцитні уявлення про оточуючий світ, людей; справедливість та керованість подій; випадковість, як шанс, надія досягти успіху; та уявлення про власне "Я"; копінг-стратеаії, як свідомий індивідуальний спосіб взаємодії особистості 3 несприятливими та потенційно стресогенними ситуаціями; часова перспектива, як здатність орієнтуватися у часі власного життя, інтегрувати минуле, теперішнє та майбутнє у психологічний життєвий простір, бачення майбутнього (його цілей, смислів); самоставлення, як смислове утворення особистості та важливий фактор ії̈ цілісності, стійкості; та самоактуалізація як потреба в здійсненні власного Я, реалізації сутнісних сил.

Здійснений теоретичний аналіз обгрунтовує наше емпіричне дослідження життєстійкості студентів з інвалідності як ресурсу особистості, визначення психологічних факторів та предикторів життєстійкості.

Методологія дослідження. В емпіричному дослідженні було використано наступні методики: шкалу життєстійкості С. Мадді (Леонтьєв, Рассказова, 2006); шкалу "World Assumptions Scale" P. Янов-Бульман в адаптації О. Кравцової (Солдатова \& Шайгерова, 2003); тест-опитувальник самоставлення (Пантілєєв, 1993); тест смисложиттєвих орієнтацій (СЖО) Дж. Крамбо, Л. Махоліка, адаптація Д. О. Леонтьєва (Леонтьєв, 1992); опитувальник копінг-стратегій Р. Лазарус, С. Фолкман, в адаптації Л. І. Вассермана (Вассерман, 2009); методика "Індекс життєвого стилю" Г. Келлермана, Р. Плутчика (Романова, Гребєннікова, 1996); опитувальник часової перспективи Ф. Зімбардо в адаптації Г. Сирцової, О.Т. Соколової, О.В. Мітіної (Сирцова, Соколова \& Мітіна, 2007); модифікований опитувальник самоактуалізації особистості (CAMOAO) Е. Шострома, в адаптації А. Лузукіна, Н. Калина (Фетискин, Козлов \& Мануйлов, 2002).

В емпіричному дослідженні взяли участь 325 студентів з інвалідністю 3 них: 130 осіб з інвалідністю за загально-соматичними захворюваннями, 102 особи 3 інвалідністю, внаслідок ураження опорно-рухового апа- 
рату, 93 особи з інвалідністю внаслідок сенсорних порушень (захворювання органів зору та слуху). Всі досліджувані студенти навчаються на різних спеціальностях Відкритого міжнародного університету розвитку людини "Україна" та Національного педагогічного університету імені М. П. Драгоманова. Вік досліджуваних від 19 до 22 років.

Для статистичного аналізу отриманих даних використовувались методи математичної статистики: описові статистики, t-критерій Стьюдента, факторний, регресійний аналіз. Обробка отриманих емпіричних результатів здійснювалася за допомогою пакету статистичних програм SPSS 21.0 for Windows.

Результати дослідження. Слід зазначити, що у більшості респондентів показники по базовим шкалам життєстійкості, нижчі за нормативні показники (Леонтьєв \& Рассказова, 2006). На рис. 1 представлено отримані дані по шкалам життєстійкості.

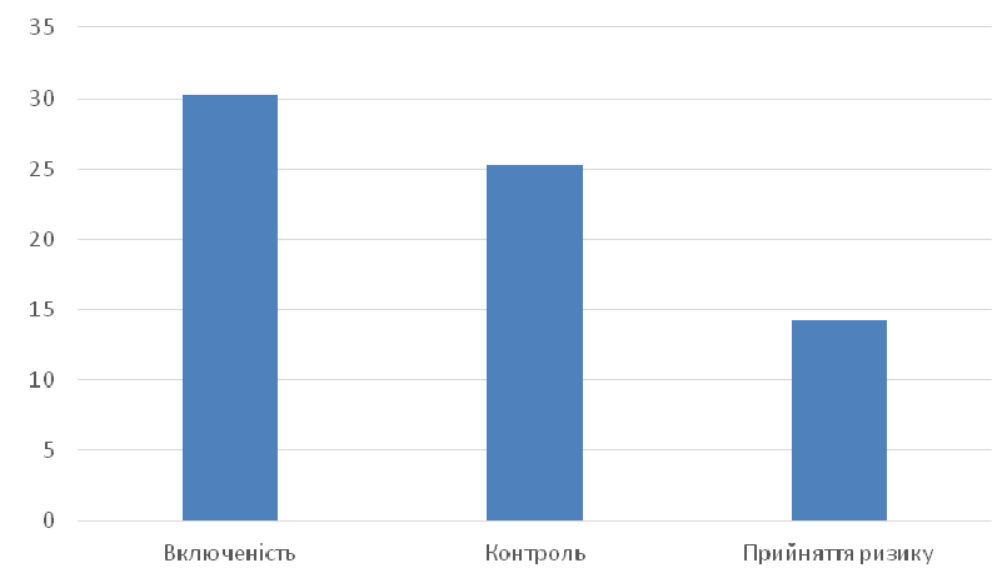

Рис. 1. Компоненти життєстійкості студентів з інвалідністю

Розподіл частотних даних показує, що у $35,2 \%$ респондентів виявлено низькі показники інтегрального показника життєстійкості (нижче 62 балів). Це свідчить, що ці респонденти не впевнені у своїх здібностях, їм властиво відчуття власної безпорадності, тому їм складно контролювати події свого життя; вони не проявляють особистісну активність у побудові власного життя, невпевнені в можливості реалізувати свої цілі та здібності, тому, часто, стикаючись з складними, стресовими ситуаціями сприймають їх як загрозу.

Середній (63-81 бал) та вище середнього (82-100 балів) рівні життєстійкості виявлено у $35,5 \%$ та $22,2 \%$, відповідно, досліджуваних студентів з інвалідністю. Ці респонденти ставляться до життєвих змін як до викликів на основі включеності, контролю та прийняття ризику; вони впевнені у силі власного Я, готові до активних дій, під час вирішення складних ситуацій, що дозволяє їм відчувати контроль над мінливими подіями свого життя; вони відкриті до оточуючого світу, нових знань, досвіду, пошуку ефективної соціальної підтримки, що сприяє розвитку навичок взаємодії та комунікації.

За інтегральним показником життєстійкості вибірку досліджуваних студентів з інвалідністю ми розділили на дві: студенти з низьким рівнем життєстійкості (показники нижче середніх нормативних) та студенти з середньо-високим рівнем життєстійкості (показники вище середніх нормативних). Відмінності виявлені між двома вибірками, за допомогою t-критерія Стьюдента, подано в рис. 2. Подано результати психологічних характеристик в яких виявлено достовірні відмінності (на рівні $0,000-0,005)$.

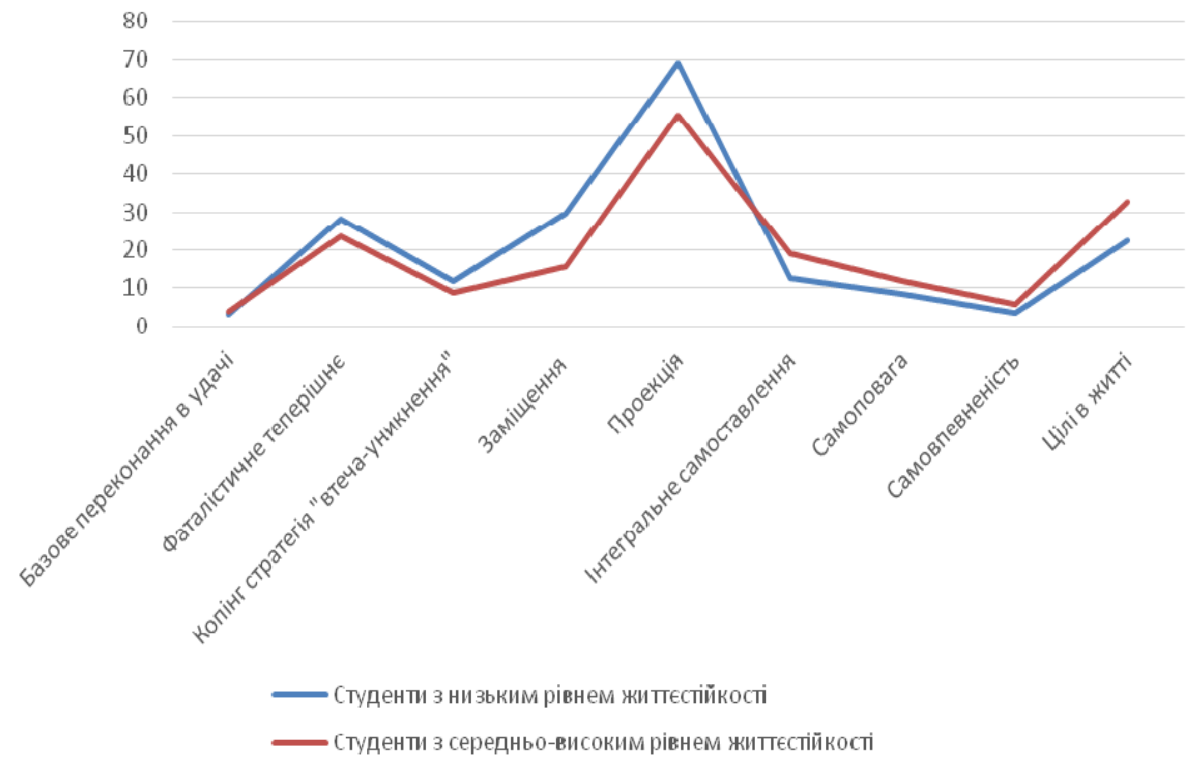

Рис. 2. Відмінності психологічних характеристик студентів з низьким та середньо-високим рівнями життєстійкості 
Отримані дані свідчать про те, що респонденти 3 низьким рівнем життєстійкості достовірно відрізняються від респондентів з середньо-високим рівнем, за параметрами: базові переконанні, часова перспектива, стратегії долаючої поведінки (копінг-стратегії), механізми психологічного захисту, самоставленням та його компонентами, смисложиттєвими орієнтаціями та потребою в самоактуалізації. Зазначені параметри особистості у студентів з низьким рівнем життєстійкості виражені слабше, ніж у студентів з середньо-високим рівнем життєстійкості.

Для визначення фракторів життєстійкості досліджуваних студентів ми використовували факторний аналіз 3 використанням методу головних компонент та метод Облімін-обертання. Відповідність даних для факторного аналізу визначалася за допомогою критерію КайзераМейера-Олкіна. Статистична достовірність результатів факторного аналізу перевірялась на основі критерію сферичності Барлетта.

На основі факторного аналізу у структурі параметрів, які забезпечують життєстійкість особистості (у вибірці досліджуваних з низьким рівнем життєстійкості) було виділено два фактори, внесок яких у загальну дисперсію даних становить 58,9\%. Показник міри адекватності КМО 0,60; Sig критерію сфреричності Бартлетта менше ніж 0,5. Отже, можемо вважати, що нами отримано достовірний факторний аналіз.

Результати факторного аналізу структури життєстійкості студентів з інвалідністю з низьким рівнем життєстійкості наведено в табл. 1.

Фактори життєстійкості студентів 3 інвалідністю з низьким рівнем життєстійкості

\begin{tabular}{|c|c|} 
Фактори життєстійкості студентів з інвалідністю з низьким рівнем життєстійкості \\
\hline Факторне навантаження & \multicolumn{1}{|c|}{ Параметри, що утворюють фактори } \\
\hline $33,4 \%$ & $\begin{array}{l}\text { Орієнтація в часі }(0,78), \text { потреба в самоактуалізації }(0,72), \text { пошук соціальної підтримки } \\
\text { копінг-стратегія) }(0,70), \text { позитивне минуле }(0,56), \text { позитивне ставлення інших }(0,55) .\end{array}$ \\
\hline $25,5 \%$ & Самоповага $(0,91)$, потреба в пізнанні $(0,75)$, позитивне минуле $(-0,63)$. \\
\hline
\end{tabular}

Перший фактор поєднує параметри: часова перспектива, активно-дієвий копінг "пошук соціальної підтримки" - емоційної, інформаційної та інструментальної, самоставлення (його складової, що відображає очікування позитивного до себе оточуючих) та потреба в актуалізації власного Я. Поєднання зазначених параметрів свідчить, що сформованість компонентів життєстійкості респондентів взаємопов'язане із здатністю студентів орієнтуватися в часі власного життя, позитивно ставитися до власного минулого; з усвідомленням потреби в самоактуалізації; здатністю ефективно використовувати соціальну підтримку та позитивно ставитися до себе, шляхом включення оцінки значущих оточуючих у власну систему самооцінок.

Поєднання параметрів у другому факторі свідчить, що індивідуальну життєстійкість респондентів забезпечують: самоповага (здатність позитивно ставитися до себе на основі власної самоефективності, компетентності), саморозвиток, шляхом пізнання оточуючого світу, використання нового досвіду, (що обумовлює здатність особистості приймати виклики життя), та сприйняття власного минулого (навіть негативних подій) як досвіду для розвитку.

Для прогнозу розвитку життєстійкості студентів з інвалідністю (з низьким рівнем інтегральної життєстійкості) ми використовували метод регресійного аналізу. Результати регресійного аналізу за яким ми можемо спрогнозувати показники життєстійкості респондентів наведено в табл. 2.

Найбільш точно прогнозує значення залежної змінної "життєстійкість" третя модель. Модель вважається дійсною, якщо R-квадрат перевищує 0,5. Отримане значення більше 0,5, тому можна стверджувати, що отримана модель $€$ статистично достовірною.

У табл. 3 наведено результуючі коефіцієнти лінійного зв'язку показника життєстійкості із особистісними характеристиками - предикторами.

Таблиця 2

\begin{tabular}{l} 
Прогностичні моделі життсстійкості студентів з інвалідністю з низьким рівнем життєстійкості \\
\begin{tabular}{|c|c|c|c|c|}
\hline Модель & $\mathbf{R}$ & $\mathbf{R}-$ квадрат & Скоригований R-квадрат & Стандартна похибка оцінки \\
\hline 3 &, $804^{c}$ &, 646 &, 616 & 5,411 \\
\hline
\end{tabular} \\
\hline
\end{tabular}

व залежна змінна: життєстійкість

Таблиця 3

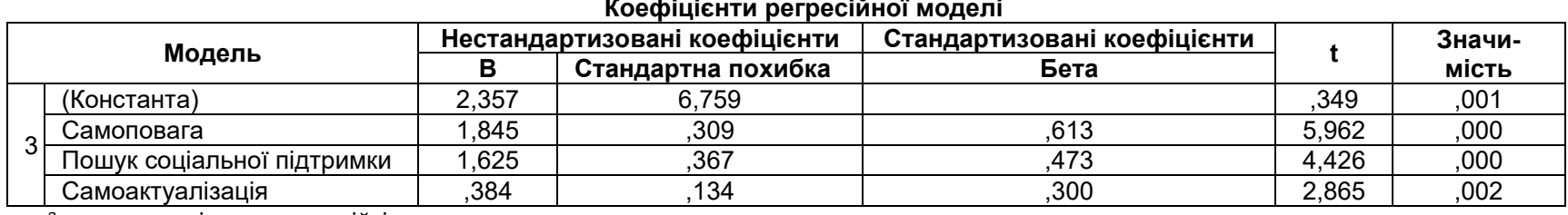

а залежна змінна: життєстійкість

Отже, у забезпеченні життєстійкості респондентів (з низьким рівнем інтегральної життєстійкості) ключову роль відіграють самоповага - як джерело власної сили, пошук соціальної підтримки - як стратегія активного діяльнісного подолання труднощів, та самоактуалізація - як потреба в саморозвитку та самореалізації. Тобто, впевненість у власній компетентності та самоефективності (самоповага), активність у реальній взаємодії з соціальним оточенням обумовлюють включеність особистості у власне життя, сприяють подоланню ізоляції, осмисленості, активізують потребу в самоактуалізації.
У вибірці студентів 3 інвалідністю 3 середньовисоким рівнем життєстійкості було виділено три фактори, внесок яких у загальну дисперсію даних становить 69,0\%. Показник міри адекватності КМО 0,76; Sig критерію сфреричності Бартлетта менше ніж 0,5. Отже, можемо вважати, що нами отримано достовірний факторний аналіз.

Результати факторного аналізу структури життєстійкості студентів 3 інвалідністю $з$ середньо-високим рівнем життєстійкості наведено в табл. 4. 
Фактори життєстійкості студентів з інвалідністю з середньо-високим рівнем життєстійкості

\begin{tabular}{|c|l|}
\hline Факторне навантаження & \multicolumn{1}{c|}{ Параметри, що утворюють фактори } \\
\hline $27,0 \%$ & $\begin{array}{l}\text { Локус контролю життя }(0,88), \text { результат життя }(0,81), \text { інтегральне самоставлення }(0,73), \\
\text { самовпевненість }(0,62), \text { майбутнє }(0,59) .\end{array}$ \\
\hline $22,7 \%$ & $\begin{array}{l}\text { Саморозуміння }(0,87), \text { самоповага }(0,69), \text { переконання в доброзичливості світу }(0,67), \\
\text { самовпевненість }(0,62) .\end{array}$ \\
\hline $19,3 \%$ & Негативне минуле $(-0,80)$, орієнтація в часі $(0,67)$, цінності $(0,59)$, регресія $(-0,54)$. \\
\hline
\end{tabular}

Перший фактор поєднує параметри: смисложитmєві орієнтації як результат усвідомлених цілей і смислу власного життя, самоставлення, як детермінанта внутрішньої активності особистості, часову перспективу як цілісний образ себе в часі.

Поєднання параметрів першого фрактору, свідчить, що життєстійкість студентів з інвалідністю, як багатокомпонентне особистісне утворення, взаємопов'язане 3 внутрішнім локусом контролю - світоглядним переконаннями про можливість керувати, контролювати своє життя, вільно приймати рішення та втілювати їх в житті; із задоволеністю самореалізацією у пройденому відрізку життя, оцінку його продуктивності та осмисленості; з позитивним ставлення до себе на основі впевненості та віри у власні здібності, енергію, самостійність, можливості, компетентність; з орієнтацією на майбутнє ("вибір майбутнього") - наявністю життєвих цілей, планів, стратегій їх реалізації, та впевненістю у власних можливостях долати труднощі (контроль).

Другий фактор поєднує параметри самоставлення (його складові) та базові переконання особистості. Це свідчить про те, що життєстійкість (та ії компоненти) пов'язані із здатністю розуміти багатогранність власного Я, приймати різні його сторони, впевненістю у власних силах, здібностях, можливостях та адекватної їх оцінки; із самоповагою (позитивним ставленням до себе на основі самоефективності, компетентності). Для студентів 3 iнвалідністю значний вплив на життєстійкість має позитивне ставлення до оточуючого світу, переконаність у його доброзичливості, що надає їм можливість реалізувати власні можливості та знайти своє місце у ньому.

Аналізуючи параметри, які утворюють третій фрактор, слід зазначити, що позитивний вплив на компоненти життєстійкості респондентів мають: здатність орієнтуватися в часі власного життя, усвідомлюючи систему власних цінностей, поділяючи цінності самоактуалізації. Негативний вплив на компоненти життєстійкості студентів 3 інвалідністю мають орієнтація на негативне минуле, імпульсивність та слабкість емоційно-вольового контролю, що визначають актуалізацію використання "незрілого" механізму "регресія" та обумовлюють зміну мотиваційно-потребової ссрери в напрямку її більшої спрощеності.

Саме постійний "вибір минулого" призводить до відчуження, яке проявляється у поєднанні безсилля та безглуздості, заперечення смислу, пошуку смислу поза межами звичної діяльності (Maddi, 2006).

Результати регресійного аналізу за яким ми можемо спрогнозувати показник життєстійкості студентів з інвалідністю (середньо-високий рівень життєстійкості) наведено в табл. 5.

Найбільш точно прогнозує значення залежної змінної "життєстійкість" друга модель. R-квадрат перевищує 0,5, тому, можна стверджувати, що отримана модель $€$ статистично достовірною.

Результуючі коефіцієнти лінійного зв'язку показника життєстійкості із особистісними параметрами - предикторами наведено в табл. 6.

Таблиця 5

Прогностичні моделі життєстійкості студентів з інвалідністю з середньо-високим рівнем життєстійкості

\begin{tabular}{|c|c|c|c|c|}
\hline Модель & $\mathbf{R}$ & $\mathbf{R}-$ квадрат & Скоригований R-квадрат & Стандартна похибка оцінки \\
\hline 2 &, $833^{\text {b }}$ &, 694 &, 684 & 6,051 \\
\hline \multicolumn{2}{l}{ П Предиктори (конст) майбутне, цінності }
\end{tabular}

скениктори (конст) майбутне, цінності

с залежна змінна: життєстійкість

Таблиця 6

Коефіцієнти регресійної моделі

\begin{tabular}{|c|c|c|c|c|c|c|}
\hline \multirow{2}{*}{\multicolumn{2}{|c|}{ Модель }} & \multicolumn{2}{|c|}{$\begin{array}{c}\text { Нестандартизовані } \\
\text { коефріцієнти }\end{array}$} & \multirow{2}{*}{$\begin{array}{c}\text { Стандартизовані } \\
\text { коефріцієнти }\end{array}$} & \multirow[t]{2}{*}{$\mathbf{t}$} & \multirow[t]{2}{*}{ Значимість } \\
\hline & & B & Стандартна похибка & & & \\
\hline \multirow[t]{3}{*}{2} & (Константа) & 19,966 & 5,400 & & 3,698 &, 000 \\
\hline & Майбутнє & 857 & ,124 &, 533 & 6,923 & 000 \\
\hline & Цінності & ,382 & ,063 & ,470 & 6,107 & ,000 \\
\hline
\end{tabular}

а залежна змінна: життєстійкість

Отже, предикторами, які позитивно впливають на показник "життєстійкість" студентів з інвалідністю $€-$ майбутнє (суб'єктивна цінність майбутнього, як особистісного ресурсу, наповненість його ціннісно-смисловим змістом) та цінності (здатність поділяти цінності, характерні для людей, які прагнуть до гармонійного буття, позитивних стосунків з оточуючими та самореалізації). Життєстійкість є тим необхідним ресурсом, який людина може використати під час вибору та побудови майбутнього. Переконаність у тому, що в майбутньому $є$ сенс, що будь-який досвід важливий у перспективі майбутнього (включеність та прийняття ризику) сприяє "вибору майбутнього", переоцінці травматичного досвіду.
Дискусія. Здобуття вищої освіти та професії для студентів з інвалідністю це - ефективний засіб соціальної затребуваності, економічної незалежності, мобільності, свободи вибору життєвих цілей та особистісної самореалізації. Однак, в умовах інклюзії здобуває освіту досить невелика частка молоді 3 інвалідністю, які наважуються на серйозний ризик, приймаючи виклик "на рівних" в умовах дефіциту особистісних ресурсів та непідготовленістю, перш за все, психологічно, освітнього середовища закладів вищої освіти (Леонтьєв, Алєксандрова \& Лебедева, 2017). Тому, важливим психолого-педагогічним завданням $€$ розвиток тих психологічних якостей які детермінують життєстійкість осо- 
бистості, як необхідний внутрішній ресурс, який забезпечує здатність і сміливість особистості залучатися до ситуацій, які змінюються, сприяє фрормуванню конструктивної життєвої позиції, підвищенню фрізичного й психічного здоров'я студентів з інвалідністю (Селіванова \& Склярова, 2020; Najmeh, 2020).

Результати нашого дослідження показують, що більшості студентів з інвалідністю властиво низький та середній рівень вираженості життєстійкості, в цілому, та її компонентів. Вираженості всіх трьох компонентів життєстійкості $є$ важливим для збереження здоров'я, оптимального функціонування та активності особистості, особливо в ускладнених умовах розвитку, які вимагають використання суттєво більших зусиль для вирішення завдань особистісного саморозвитку (Щєтініна, 2015; Maddi, 2004).

Важливе значення в забезпеченні особистісної стійкості студентів з інвалідністю, з низьким рівнем вираженості життєстійкості, має соціальна підтримка (на відміну від соціального захисту, допомоги, характеризується активністю суб'єкта, спрямованої на самостійне подолання складної життєвої ситуації), яка дозволяє здійснювати смислову переоцінку ситуації, як більш позитивної (Алєксандрова \& Сілантьєва, 2014), сприяє психічному здоров'ю, розвитку та саморозвитку особистості; та самоповага на основі пізнання власних сильних та ресурсних якостей, розвиток яких буде сприяти самоефективності особистості та здатності перетворювати складні ситуації в діяльності на ресурс власного розвитку (Najmeh, 2020).

Пошук ефективної соціальної підтримки є одним 3 основних механізмів, за допомогою якого, життєстійкість виконує буферну функцію під час різноманітних захворювань (Maddi, 2006).

\section{Висновки}

1. Визначено, що в забезпеченні життєстійкості студентів з низьким рівнем вираженості її компонентів, значущості набувають параметри: часова перспектива; активно-дієві копінг-стратегії, зокрема "пошук соціальної підтримки"; самоставлення особистості, у розвитку якого важливим є орієнтація на оцінки інших, та позитивне ставлення оточуючих; потреба в актуалізації власного Я. Поєднання зазначених параметрів свідчить, що сформованість компонентів життєстійкості взаємопов'язане із здатністю респондентів орієнтуватися в часі власного життя, з наявністю потреби в самоактуалізації, здатністю ефективно використовувати соціальну, емоційну та дієву підтримку оточуючих.

2. Встановлено, що найбільш точно прогнозують значення показника життєстійкості, у респондентів 3 низьким рівнем вираженості її компонентів, предиктори: самоповага - як джерело власної сили, самоефективності та саморегуляції; пошук соціальної підтримки - як стратегія активного діяльнісного подолання труднощів, та самоактуалізація - як потреба в реалізації власної сутності. Зазначені предиктори можна вважати психологічними ресурсами життєстійкості студентів з інвалідністю, цілеспрямоване формування яких буде сприяти саморозвитку особистості, трансформації перешкод, складних ситуацій у джерело розвитку та росту.

3. Доведено, що факторна структура показників у групі студентів з середнім та високим рівнями вираженості компонентів життєстійкості характеризується поєднанням параметрів: смисложиттєві орієнтації як результат усвідомлених цілей і смислу власного життя, самоставлення, як детермінанта внутрішньої активності особистості, часова перспектива - як цілісний образ себе в часі, базові переконання особистості - як імпліцитні уявлення індивіда про оточуючий світ, людей, самого себе та стосунків зі світом, цінності - як здат- ність керуватися у взаємодії з оточуючим світом цінностями самоактуалізації.

4. Ключовими предикторами життєстійкості студентів з інвалідністю (з середньо-високим рівнем вираженості її компонентів) $€$ - майбутнє (параметр часової перспективи особистості) та цінності самоактуалізації. Наповненість майбутнього цінностями самореалізації, усвідомленими життєвими цілями, особистісним смислом сприяє "вибору майбутнього" (нового, невизначеного, непередбачуваного), обумовлюють здатність суб'єкта планувати та будувати власне майбутнє, приймати життєві виклики, прикладати власні вольові зусилля та мужність у процесі особистісної самореалізації.

Виявлені в результаті нашого емпіричного дослідження параметри особистості є ресурсами життєстійкості студентів 3 інвалідністю та умовою їх успішної самореалізації.

Список використаних джерел

1. Александрова, Л.А., Силантьева, Т.А. (2014). Социальная поддержка студентов с ОВЗ в условиях инклюзивного образования [Электронный ресурс], Клиническая и специальная психология, 3, 2. URL: https://psyjournals.ru/psyclin/2014/n2/Aleksandrova_Silant'eva.shtml (дата звернення: 01.11.2020

2. Вассерман, Л. И. (2009). Методика для психологической диагностики способов совладания со стрессовыми и проблемными для личности ситуациями. Пособие для врачей и медицинских психологов. СПб: Психоневрологический институт им. В.М. Бехтерева.

3. Купрєєва, О.І. (2020). Ціннісно-смислові основи самореалізації студентів в інтегрованому освітньому середовищі. Актуальні проблеми психології: Збірник наукових праць Інституту психології імені Г.С. Костюка НАПН України, VI, $17,167-176$.

4. Леонтьев, Д., Рассказова, Е. (2006). Тест жизнестойкости. Москва: Смысл, 2006.

5. Леонтьев, Д.А. (1992). Тест смысложизненных ориентаций (СЖО). М.: Смысл, 1992.

6. Леонтьев, Д.А., Александрова, Л.А., Лебедева, А.А. Развитие личности и психологическая поддержка учащихся с ОВЗ в условиях инклюзивного профрессионального образования. - Москва: Смысл, 2017. - 79 с.

7. Осьмук, Л.А. (2018). Самореализация студентов с инвалидностью как базовый механизм социальной инклюзии. Психологическая наука и образование, 23, 2, 59-67. Doi: 10.17759/ pse.2018230207

8. Романова, Е.С., Гребенникова, Л.Р. (1996). Механизмы психологической защиты. Генезис. Функционирование. Диагностика. Мытищи: Талант.

9. Селиванова, Ю.В., Склярова, Т.В. (2020). Личностное самоопределение студентов с инвалидностью: социально-психологический анализ фокторов и механизмов. Вестник Мининского университета, 8, 2, 8. DOI: $10.26795 / 2307-1281-2020-8-2-8$

10. Сердюк, Л.З., Купрєєва, О.І. (2015). Особистісний ресурс життєстійкості студентів із соматичними захворюваннями. Актуальні проблеми психології: збірник наукових праць Інституту психології імені Г. С. Костюка НАПН України, IX, 7, 311-317.

11. Сырцова, А., Соколова, Е.Т., Митина, О.В. (2007). Методика Ф. Зимбардо по временной перспективе на русскоязычной выборке. Психологическая диагностика, 1, 85-106

12. Фетискин, Н.П., Козлов, В.В., Мануйлов, Г.М. (2002). Социальнопсихологическая диагностика развития личности и малых групп. М.: Прогресс, 426-433.

13. Шайгерова, Л.А., Прокофьева, Л.Ю., Кравцова, О.А., Солдатова, Г.У. (2003). Практикум по психодиагностике и исследованию толерантности личности (учебно-методическая разработка). - М. Центр СМИ МГУ им. М.В. Ломоносова, 2003.

14. Шамич, О. М. (2019). Психологічні основи самореалізації паралімпійців: монографрія. - К.: Талком, 2019.

15. Щетинина, Е. Б. (2015). Жизнестойкость студентов с ограниченными возможностями здоровья как фактор успешной социальнопсихологической адаптации к среде высшего образовательного учреждения. Акмеология образования, 4, 4(16), 306-309. DOI: 10.18500/2304дения. Акмеология образ

16. Bandura, A. (1997). Self-efficacy: Toward a unifying theory of behavioral change. Psychological Review, 191-215. DOl: https://doi.org/10.21277/sw.v1i9.454

17. Hong Barbara S.S. (2015). Qualitative Analysis of the Barriers College Students With Disabilities Experience in Higher Education. Journal of College Student Development, 56, 3. 209-226. DOI: 10.1353/csd.2015.0032.

18. Jomehri, F, Najafi, M, Jafari E, Sohrabi, F. (2009). The relationship between type personality, locus of control and hardiness in patients suffering from cancer and normal subjects. Journal of Clinical Psychology, 1. 47-66. Available from: http://scholar.google.com/scholar?hl=en\&as_sdt= $0 \% 2 \mathrm{C} 5 \& \mathrm{q}=\mathrm{J}$ omehri+F\%2C+Najafi+M\%2C+Jafari+E\%2C+Sohrabi+F.+The+ relationship\&btnG=

19. Khoshaba D., \& Maddi S. (1999). Early antecedents of hardiness. Consulting Psychology Journal, 51(2), 106-117.

20. Maddi, S.R. (2004). Hardiness: An Operationalization of Existential Courage. Journal of Humanistic Psychology, 44, 3, 279-298. 
21. Maddi, S.R. (2006). Hardiness: The courage to grow from stresses. The Journal of Positive Psychology, 1(3). 160-168.

22. Maddi, S.R. (2013). Hardiness. Turning stressful circumstances into resilient growth. Springer Netherlands, Irvine, CA. DOI 10.1007/978-94-007-5222-1

23. Maddi, S.R., Khoshaba, D.M., Harvey, R.H., \& Fazel, M. (2010). The personality construct of hardiness. Relationships with the construction of existential meaning in life. Journal of Humanistic Psychology, 3(51), 369-388.

24. Mahdian, Z, Ghaffari ,M. (2016). The mediating role of psychological resilience, and social support on the relationship between spiritual well-being and hope in cancer patients. Journal of Fundamentals of Mental Health, 18. Available from: http://scholar.google.com/scholar?hl=en\&as_sdt=0\%2C5\&q=Mahdian+Z\%2C+ Ghaffari+M.+The+mediating+role+of+psychological\&btnG=)

25. Najmeh, H. (2020). Study of the Relationship of Hardiness and Hope with Life Satisfaction in Managers. International Journal of Psychology. 14, (1), Winter \& Spring, 310-339. Doi: 10.24200/IJPB.2020.214143.1143

26. Peterson, C., \& Seligman, M.E.P. (Eds.). (2004). Character strengths and virtues: A handbook and classification. N.Y.: Oxford University Press.

27. Ryff, C. \& Singer, B. (1998). The contours of positive human health. Psychological Inquiry, 9, 1-28.

28. Schwarzer, R., Jerusalem, M. (1995). Generalized Self-Efficacy scale. In J. Weinman, S. Wright, M. Johnston, Measures in health psychology: A user's portfolio. Causal and control beliefs (pp. 35-37). Windsor, UK: NFER-NELSON.

29. Seligman, M.E.P., \& Csikszentmihalyi, M. (2000). Positive psychology. American psychologist, 55(1), 5-14

30. Serdiuk L., Danyliuk I., Chykhantsova O. Psychological factors of secondary school graduates' hardiness. Social Welfare: Interdisciplinary Approach. 2019. Vol. 1. P. 93-103.

\section{References}

1. Aleksandrova, L.A., Silant'eva, T.A. (2014). Social'naja podderzhka studentov s OVZ v uslovijah inkljuzivnogo obrazovanija [Jelektronnyj resurs], Klinicheskaja i special'naja psihologija, 3,2 .

2. Vasserman, L. I. (2009). Metodika dlja psihologicheskoj diagnostiki sposobov sovladanija so stressovymi i problemnymi dlja lichnosti situacijami. Posobie dlja vrachej i medicinskih psihologov. SPb: Psihonevrologicheskij institut im. V.M. Behtereva

3. Kupryeyeva, O.I. (2020). Cinnisno-smyslovi osnovy samorealizaciyi studentiv $v$ intehrovanomu osvitn"omu seredovyshhi. Aktual"ni problemy psyxolohiyi: Zbirnyk naukovyx prac" Instytutu psyxolohiyi imeni H.S. Kostyuka NAPN Ukrayiny, VI, 17, 167-176.

4. Leont'ev, D., Rasskazova, E. (2006). Test zhiznestojkosti. Moskva: Smysl.

5. Leont'ev, D.A (1992). Test smyslozhiznennyh orientacij (SZhO) M: Smysl.

6. Leont'ev, D.A., Aleksandrova, L.A., Lebedeva, A.A. Razvitie lichnosti i psihologicheskaja podderzhka uchashhihsja s OVZ v uslovijah inkljuzivnogo professional'nogo obrazovanija. Moskva: Smysl. 2017. 79 s.

7. Os'muk, L.A. (2018). Samorealizacija studentov s invalidnost'ju kak bazovyj mehanizm social'noj inkljuzii. Psihologicheskaja nauka obrazovanie, 23, 2, 59-67. Doi: 10.17759/ pse.2018230207

8. Romanova, E.S., Grebennikova, L.R. (1996). Mehanizmy psihologicheskoj zashhity. Genezis. Funkcionirovanie. Diagnostika. Mytishhi: Talant

9. Selivanova, Ju.V., Skljarova, T.V. (2020). Lichnostnoe samoopredelenie studentov s invalidnost'ju: social'no-psihologicheskij analiz faktorov i mehanizmov. Vestnik Mininskogo universiteta, 8, 2, 8. DOI: 10.26795/2307-1281-2020-8-2-8

10. Serdyuk, L.Z., Kupryeyeva, O.I. (2015). Osobystisnyj resurs zhyttyestijkosti studentiv iz somatychnymy zaxvoryuvannyamy. Aktual"ni problemy psyxolohiyi: zbirnyk naukovyx prac" Instytutu psyxolohiyi imeni H. S. Kostyuka NAPN Ukrayiny, IX, 7, 311-317
11. Syrcova, A., Sokolova, E.T., Mitina, O.V. (2007). Metodika F. Zimbardo po vremennoj perspektive na russkojazychnoj vyborke. Psihologicheskaja diagnostika, 1, 85-106

12. Fetiskin, N.P., Kozlov, V.V., Manujlov, G.M. (2002). Social'no-psihologicheskaja diagnostika razvitija lichnosti i malyh grupp. M.: Progress, 426-433.

13. Shajgerova, L.A., Prokof'eva, L.Ju., Kravcova, O.A., Soldatova, G.U. (2003). Praktikum po psihodiagnostike $\mathrm{i}$ issledovaniju tolerantnosti lichnosti (uchebno-metodicheskaja razrabotka). M. Centr SMI MGU im. M.V. Lomonosova.

14. Shamych, O. M. (2019). Psyxolohichni osnovy samorealizaciyi paralimpijciv: monohrafiya. K.: Talkom.

15. Shhetinina, E B (2015). Zhiznestojkost' studentov s ogranichennymi vozmozhnostjami zdorov'ja kak faktor uspeshnoj social'no-psihologicheskoj adaptacii $\mathrm{k}$ srede vysshego obrazovatel'nogo uchrezhdenija. Akmeologija obrazovanija, 4, 4(16), 306-309. DOI: 10.18500/2304-9790-2015-4-4-306-309.

16. Bandura, A. (1997). Self-efficacy: Toward a unifying theory of behavioral change. Psychological Review, 191-215. DOI: https://doi.org/10.21277/sw.v1i9.454

17. Hong Barbara S.S. (2015). Qualitative Analysis of the Barriers College Students With Disabilities Experience in Higher Education. Journal of College Student Development, 56, 3. 209-226. DOI: 10.1353/csd.2015.0032.

18. Jomehri, F, Najafi, M, Jafari E, Sohrabi, F. (2009). The relationship between type personality, locus of control and hardiness in patients suffering from cancer and normal subjects. Journal of Clinical Psychology, 1. 47-66. Retrieved from http://scholar.google.com/scholar?hl=en\&as_sdt=0\%2C5\&q= Jomehri+F\%2C+Najafi+M\%2C+Jafari+E\%2C+Sohrabi+F + The+relationship\&btnG=.

19. Khoshaba D., \& Maddi S. (1999). Early antecedents of hardiness. Consulting Psychology Journal, 51(2), 106-117.

20. Maddi, S.R. (2004). Hardiness: An Operationalization of Existential Courage. Journal of Humanistic Psychology, 44, 3, 279-298.

21. Maddi, S.R. (2006). Hardiness: The courage to grow from stresses. The Journal of Positive Psychology, 1(3). 160-168.

22. Maddi, S.R. (2013). Hardiness. Tuming stressful circumstances into resilient growth. Springer Netherlands, Irvine, CA. DOI 10.1007/978-94-007-5222-1

23. Maddi, S.R., Khoshaba, D.M., Harvey, R.H., \& Fazel, M. (2010). The personality construct of hardiness. Relationships with the construction of existential meaning in life. Journal of Humanistic Psychology, 3(51), 369-388.

24. Mahdian, Z, Ghaffari ,M. (2016). The mediating role of psychological resilience, and social support on the relationship between spiritual wellbeing and hope in cancer patients. Journal of Fundamentals of Mental Health 18. Retrieved from http://scholar.google.com/scholar?hl=en\&as sdt $=0 \% 2 \mathrm{C} 5 \& \mathrm{q}=$ Mahdian $+\mathrm{Z} \% 2 \mathrm{C}+$ Ghaffari+M. + The + mediating +role + of + psyc hological\&btnG=

25. Najmeh, H. (2020). Study of the Relationship of Hardiness and Hope with Life Satisfaction in Managers. International Journal of Psychology. 14, (1), Winter \& Spring, 310-339. Doi: 10.24200/IJPB.2020.214143.1143

26. Peterson, C., \& Seligman, M.E.P. (Eds.). (2004). Character strengths and virtues: $A$ handbook and classification. N.Y.: Oxford University Press.

27. Ryff, C. \& Singer, B. (1998). The contours of positive human health. Psychological Inquiry, 9, 1-28.

28. Schwarzer, R., Jerusalem, M. (1995). Generalized Self-Efficacy scale. In J. Weinman, S. Wright, M. Johnston, Measures in health psychology: A user's portfolio. Causal and control beliefs (pp. 35-37). Windsor, UK: NFER-NELSON.

29. Seligman, M.E.P., \& Csikszentmihalyi, M. (2000). Positive psychology. American psychologist, 55(1), 5-14.

30. Serdiuk L., Danyliuk I., Chykhantsova O. Psychological factors of secondary school graduates' hardiness. Social Welfare: Interdisciplinary Approach. 2019. Vol. 1. P. 93-103.

Надійшла до редколегії 15.09.20

Olga Kuprieieva, PhD (Psychology)

Taras Shevchenko National University of Kyiv, Kyiv, Ulkraine

\section{THE PSYCHOLOGICAL FACTORS OF DISABLED STUDENTS' PSYCHOLOGICAL HARDINESS}

The article presents the empirical study on the psychological factors of disabled students' psychological hardiness. Studying in integrated groups is a challenge of particular difficulty for disabled students who dare to exercise their rights to higher education and equal opportunities proposed by the inclusive environment, which requires from them much more efforts than those in situations of chronic illness, as well as activation of their personal resources. Therefore, it is important to study psychological hardiness as a general indicator of an individual's mental health, determining their ability to overcome life difficulties. The aim is to study the psychological characteristics, factors and predictors that determine disabled students' psychological hardiness. Methods. Factor analysis allowed us to determine the parameters of psychological hardiness for disabled students having different intensity of its components. According to the performed regression analysis, the indicators of disabled students' psychological hardiness having low and medium-high general hardiness are predicted. Results and conclusions. The factor structure of psychological hardiness for disabled students having low intensity of its components includes the following parameters: time perspective; active coping strategies; self-attitude, with the focus on assessment of them from others and an expected positive attitude of others; the need to actualize one's own Self. The predictors determining these respondents' psychological hardiness are self-esteem as a source of one's own strength, the search for social support as a strategy for active overcoming of difficulties, and self-actualization as a need for self-development and self-realization. The factor structure of psychological hardiness for disabled students having medium-high intensity of its components includes the following parameters: meaningful life orientations as a result of existing conscious goals and meanings for their lives; good self-attitude as a determinant of an individual's internal activity, time perspective as a holistic self-image in time; the individual's basic beliefs as their implicit ideas about the world around, other people, themselves and relationships with the world; values as an ability to be guided in interaction with the world around by the values of self-actualization. Predictors that determine these respondents' psychological hardiness are: the future (as a parameter of an individual's time perspective) and the values of self-actualization. The personality parameters revealed at our empirical research are the resources of disabled students' psychological hardiness and the condition of their successful self-realization.

Keywords: psychological hardiness, disabled students, personal resources, integrated learning. 